\title{
Toplumsal Bütünleşme Bağlamında Sosyal Sermaye ve Çokkültürcülük
}

Yılmaz Ceylan*

Öz

Toplumsal bütünleşme son dönemde toplumların en çok ihtiyaç duyduğu dolayısıyla hükümetlerin de kendisine dair ciddi uğraşlar içinde olduğu bir husustur. Bu bağlamda, özellikle modern dönemde çeşitli nedenlerle oluşmuş çokkültürlü yapı devletler için en önemli sorunmuş gibi durmaktadır. Toplumsal bütünleşmeyi sağlamak adına farklı toplulukları ortak norm ve değerler çerçevesinde; ortak bir amaçta buluşturmak, devletlerin en önemli görevi haline gelmiştir. Son dönemde sıklıkla gündeme gelen iki teorinin bu anlamda ilgi çektiği söylenebilir: Sosyal sermaye ve çokkültürcülük. Her iki teorinin de farklı kültürlerin bütünleşmesine dair pek çok ortak noktada buluştuklarını söylemek mümkündür. Bu nedenle bu çalışmada "Çağdaş liberal ve sosyal demokrat eşitlikçilik anlayışı çerçevesinde doğan çokkültürcülük bağlamında çoğulcu davranan ve birlikte yaşama kültürünün iyi örneğini sergileyen devletler sosyal sermayenin güçlü olduğu ülkeler midir?" ya da "Sosyal sermayesi güçlü olan ülkeler çokkültürcü bir politika mı izlemektedir?" sorularına cevap aranmaya çalışılmıştır. Sonuç olarak ayrıştırma, ötekileştirme ve ırkçılı̆̆ın olmadığı güven ve huzurun olduğu topluluklarda, sosyal sermaye ve çokkültürcülüğün korelasyonunu anlamak üzere bazı yorum ve çıkarımlarda bulunulacaktır.

Anahtar Kelimler: Toplumsal Bütünleşme, Çokkültürcülük, Sosyal Sermaye.

Social Capital and Multiculturalism in the Context of Social Integration

\section{Abstract}

Social integration is an issue which societies have needed most and thus governments have dealt with seriously in recent times. In this context, the multicultural structure, which was created for various reasons especially in the modern period, seems to be the most important problem for the states. It has become the most important duty of the states to bring different communities together for a common purpose within the framework of common norms and values in order to ensure social integration. It can be said that two theories that have come to the fore a lot recently draw attention in this sense: Social capital and multiculturalism. It is possible to say that both theories meet at many common points regarding the integration of different cultures. Therefore, in this study, answers are sought for the following questions: "Are the states which act in a pluralistic way in the context of multiculturalism arising within the framework of contemporary liberal and social democratic egalitarianism and which set good examples of cultures of coexistence, the countries where social capital is strong as well?" or "Do countries with strong social capital follow a multicultural policy?" As a result, comments and inferences will be made to understand the correlation of social capital and multiculturalism in the communities where there is no segregation, marginalization and racism but trust and peace.

Key Words: Social Integration, Multiculturalism, Social Capital.

‘Dr. Öğr. Üyesi | Muş Alparslan Üni., Felsefe ve Din Bilimleri Bölümü | y.ceylan@alparslan.edu.tr ORCID: 0000-0003-4643-3461 | DOI: 10.36484/liberal.753261

Liberal Düşünce Dergisi, Yıl: 25, Sayı: 100, Güz 2020, ss. 69-90.

Gönderim Tarihi: 15 Haziran 2020 | Kabul Tarihi: 23 Aralık 2020 


\section{Giriş}

Devlet yönetimi, toplumsal bütünleşme, birlikte yaşama kültürü ve haklar, kadim bir tartışma geleneğine sahiptir. İnsanın sosyal bir varlık olması ve bir topluluk içinde kendini bulması, örgütlü olmanın ve daha organize hale gelmenin de bir neticesi olarak her türlü birlikte yaşama tecrübesi farklı tartışmaları beraberinde getirmiştir. Dünya üzerinde birlikte yaşama tecrübesini başarmış olan ve başaramayan toplumlar şeklinde bir kategorileştirme mümkün gibi durmaktadır. Ancak son dönemde kendi içinde sorunlara demokratik çözümler bulmuş ya da bulmaya çalışan farklı kültürlerden halkları aynı devlet çatısı altında huzur ve güven içerisinde yaşatan toplumların ürettikleri yeni bir sermaye çeşidinden bahsedilir olmuştur. Bu sermaye çeşidi güven indeksi olarak bilinen sosyal sermayeden başkası değildir. Bu bağlamda kendi içinde farklı kültürleri barındıran devletler için birlikte yaşama ve toplumsallığın kendine yer bulabileceği en önemli modern karşılığın ise çokkültürcülük olduğu söylenebilir. Birlikte yaşamaya dair en insani yanıt olma iddiasında olan çokkültürcülüğün hem dinsel hem etnik hem de dilsel bir eşit halklar iddiası bu anlamda elini güçlendirmektedir.

Toplumsal bütünleşme noktasında çokkültürlülük bazen olumlu bazen de olumsuz sonuçlara neden olabilir. Bu çeşitliliği olumlu yönde kullanabilme adına yani halklar arasındaki güven ve barışı sağlama adına son dönem önemli olan iki teoriden bahsedilir olmuştur: Sosyal sermaye ve çokkültürcülük. Çünkü bütünleşme birkaç bileşenden müteşekkildir ve bunlar sosyo-politik özelliklere sahiptir. Çokkültürcülük ulusal ve etnik farklılıkları istikrarlı ve ahlaki bakımdan savunulabilir bir biçimde düzene sokma iddiasındadır. Sosyal güven, ilişkiler ağı ve ortak normlar olarak ifade edilebilecek olan sosyal sermaye toplumsal dayanışma ve bütünleşmenin en güçlü unsuru olarak ifade edilebilir. Birlikte yaşama kültürünün temelini oluşturan pek çok durum hem sosyal sermayeye hem çokkültürcülük politikalarına kaynaklık etmektedir. Hem çokkültürcülük politikaları hem de sosyal sermaye için yurttaşların ortak bir amaç ve dayanışma duygusu içinde olması temel hedeflerden biridir.

Çokkültürcülük yanlısı açıklama yapan isimler sağlıklı bir yurttaşlık ve istikrarlı bir toplumsal barış sürecinin çokkültürcülük sayesinde olacağını savunurken, çokkültürcülük karşıtı görüş, ortak bir yurttaşlık kimliği geliştirmenin tek yolunun ortak bir yurttaşlık statüsü yaratmaktan geçtiğini savunur. Bunlardan hangisinin istikrarlı bir barış ve ortak değerler üreteceği tartışması aynı zamanda sosyal sermaye tartışmalarını da ilgilendirmektedir. Çünkü ülke bütünlüğü, sağlıklı bir toplumsal bütünleşme ve istikrarlı bir barış, sosyal sermayenin de önemli unsurlarındandır. Bu açıdan çokkültürcülük teorisine dair 
yapılan tartışmalar aynı zamanda sosyal sermaye teorisi için de yapılmakta ve bunlar toplumsal bütünleşmenin önemli unsurlarından sayılmaktadır. Bu çalışmada çokkültürcülük politikaları ve sosyal sermaye bağlamında yapılan tartışmalara toplumsal bütünleşme açısından bakılmaya çalışılmış ve çokkültürcü politika izleyen ülkelerin sosyal sermayelerinin de aynı zamanda yüksek oluşuyla toplumsal barışın ilişkisine dikkat çekilmiştir. Bu yapılırken çokkültürcülük teorisini savunanların yanı sıra ona karşı çıkanların görüşlerine çokkültürcülük teorisi şemsiyesi altında yer verilmiştir. Sonuç olarak çokkültürcülük ve sosyal sermaye teorilerine dair yapılan tartışmaların toplumsal bütünleşmeye ciddi katkılar sunduğunu söylemek mümkündür.

\section{Sosyal Sermaye}

Sosyal sermaye için tam anlamıla bir tanım yapılamasa da karşılık bulduğu kavram bireyler arası ve kurumlara duyulan güven, bölgesel kalkınma paydaşları arasındaki ilişkiler ağı ve bunun etkinliği, ortak normlar, iş birliği, karşılıklılık, ortak hedeflere ulaşma ve sosyal hayata katılım olarak ifade edilebilir. Kısacası sosyal sermaye sürdürülebilir bir refah seviyesinin olmazsa olmaz kayıp halkası (missing link) olarak ifade edilebilir. Kavram pek çok farklı değişken, yaklaşım ve uygulamayla özellikle iktisat, siyaset bilimi, sosyoloji, antropoloji yazınında ancak genellikle tüm sosyal bilimleri kapsar niteliktedir. Kavramın tanımına dair belirsizliğin nedeni ise, farklı disiplinlerden gelen araştırmacıların sosyal sermayeyi, kendi bakış açılarına göre ele almalarında aranabilir.

Sosyal sermaye genellikle işlevi ile tarif edilir (Coleman, 1990: 302; Harriss ve Renzi, 2010: 10; Fukuyama, 2010: 143). Coleman sosyal sermaye için "aile ilişkileri ve cemaatin toplumsal örgütlenmesinin doğasında var olan ve ayrıca çocukların veya gençlerin bilişsel ve sosyal gelişimi için yararlı bir dizi kaynağı" ifade etmektedir (Harriss ve Renzi, 2010: 10). Putnam da eğitim, kentsel yoksulluk, işsizlik, suç ve uyuşturucu kontrolü ve hatta sağlık alanında ortaya çıkan başarılı sonuçların daha çok sivil katılımın yoğun olduğu eş deyişle sosyal sermeyesi güçlü olan topluluklarda gerçekleştiğini ifade etmiştir (Putnam, 2010: 122). Fukuyama ise sosyal sermayeyi iki ya da daha fazla birey arasında iş birliğini destekleyen gayri resmi norm olarak açıklamaktadır (Fukuyama, 2002: 27). Ona göre sosyal sermaye din, gelenek, tarihsel deneyim ve hükümetin kontrolü dişında yer alan diğer unsurların yan ürünüdür (Fukuyama, 2010: 143-144, 166).

Geleneksel toplumlarda devletin topraklarının güvenliği üzerinden oluşan risk, modern dünyada artık evin içine girmiş durumdadır (Giddens, 1994; 
Okumuş, 2017). ${ }^{1}$ Bunun üstesinden gelmek için siyaset felsefecilerinin, sosyologların, siyaset bilimcilerin farklı bakış açıları ve teorileri mevcuttur. Risk toplumu haline gelmiş yenidünya düzeninin daha güvenli bir noktaya evrilmesi için ortaya çıkan ve önemli katkılar sunan önemli unsurlardan bir tanesinin sosyal sermaye teorisi olduğu söylenebilir (Kılınç, 2010: 3; Aydemir ve Özşahin, 2011: 43; Yarcı, 2011: 125). Eğitim, aile, iş hayatı, komşuluk ilişkileri, yeni ilişki alanları, açılan-kapanan sınırlar, göçler, ekonomik yetersizlik ve eşitsizlikler, yeni hastalıklar, artan suç oranları insanların güvenli bir dünya arayışını hızlandırmıştır. Bu arayışın temelini çok öncelere götürebilmek mümkündür. Ancak alanyazında sosyal sermaye kavramını ilk kullanan Lyda J. Hanifan (1916), sonra Homans (1961), daha sonra Jakops (1961) ve Loury (1977) olmuştur. Sosyal sermaye kavramını şimdiki anlamıyla ilk kullananların James Coleman $(1987,1988,1990)$ ve Robert Putnam $(1993,1995)$ olduğu söylenebilir (Woolcock and Narayan, 2000: 229; Smart, 2008; Grooteart, 2010: 224-225; Özcan ve Zeren, 2013: 9). Ancak sosyal sermayenin kavramsallaştırılmasında Pierre Bouerdieu ve Francis Fukuyama'nın önemli katkıları olmuştur. Özellikle Robert D. Putnam'ın İtalya üzerine olan çalışması Making Democracy Work ve daha sonra Amerika üzerine olan çalışması Bowling Alone sosyal sermaye adına yapılmış ilk çalışmalar olarak sayılabilir.

Alanyazında sosyal sermaye genellikle ekonomik kalkınma için bir ön koşul ya da önemli bir destekçi şeklinde ifade edilmektedir. Sosyal sermaye kavramıyla özellikle iktisatçıların ilgilenmesi ve son dönem çok yaygın bir şekilde kullanılmasının altında yatan şey de biraz budur. Mesela Dünya Bankası sosyal sermayeyi Fukuyama'yla (2002: 27) benzer şekilde ortak faaliyeti sağlayan normlar ve ağlar şeklinde tanımlamakta ve bunun yoksulluğun azaltılması ve sürdürülebilir insani ve ekonomik kalkınma için yaşamsal bir öneme sahip olduğunu ifade etmiştir. Kimi yazarlar için sosyal güven, kimileri için sosyal ağlar, kimileri için ise sosyal normlar olarak ifade edilen sosyal sermaye beşeri ve fiziksel sermayeyle birlikte etkileşim içerisine girerek ya da dolaylı şekilde işlem maliyetini indirerek, kolektif eylem ve dışsallık kaynaklı problemleri çözerek ülkenin kalkınmışlık düzeyine katkıda bulunmaktadır (Özcan ve Zeren: 2013). Buradan çıkarılacak sonuç, sosyal sermayenin diğer sermaye türleriyle birlikte kalkınma sürecinin bir elemanı olduğudur.

Sosyal sermayesi güçlü olan toplumlarda hayatın daha kolay olduğu ve toplumların daha mutlu oldukları söylenebilir (Uğuz ve Diğerleri, 2011: 10). Sivil katılım, karşılıklılığın güçlü normlarını besler ve bu sayede sosyal güvenin ortaya çıkmasını sağlar. Bu da halklar arasında iş birliğini ve iletişimi

1 Risk toplumu kavramının daha iyi anlaşılabilmesi için kuramın sahibi Ulrick Beck'in Risk Toplumu: Başka Bir Modernliğe Doğru çalışmasına bakılabilir. 
kolaylaştırır (Putnam, 2010: 125). Bu anlamda sosyal sermaye modern ekonomiler için önemli bir unsurken liberal demokrasiler için de olmazsa olmaz koşul olarak kabul edilebilir. Eş deyişle sosyal sermaye, rasyonalite, hukuk kuralları ve biçimsel kurumlar temelinde oluşmuş modern toplumların kültürel unsurudur (Fukuyama, 2010: 143). Toplumların kutuplaşmasını ve bütünlüğünü bozan derin çatlaklar bu sayede ortadan kaldırılmış olur. $\mathrm{Bu}$ açıdan sosyal sermaye, eğitimde olduğu gibi hem bir neden hem de sonuçtur denebilir. Bir topluluğun sosyal sermayesinin bu noktada güçlü olmasını sağlayan önemli unsurlardan birinin çokkültürcülük olduğu söylenebilir.

Sosyal sermayenin göstergeleri olarak sivil toplum, sivil katılım, iyi komşuluk, adalet, arkadaşlık, sosyal güven gibi pozitif değerler çokkültürcülük politikasının ötekileştirmeden birlikte yaşama iddiasını destekler nitelikteki özelliklerdir. Bu anlamda çokkültürcülüğün neredeyse bütün kolektif vaatleriyle sosyal sermaye indeksinin ilgileşim içinde olduğu söylenebilir. Olson konuyla alakalı "Düşük gelirli ülkelerin yatırım, uzmanlık ve ticaretten (çok büyük kaynaklara dayansalar bile) büyük kazançlar elde edemeyeceklerini söyler, çünkü uzun dönemde sözleşmelere uyulmasını sağlayacak ve mülkiyet haklarını koruyacak kurumlardan yoksundurlar ve yanlış yönlendirilen ekonomi politikalarına sahiptirler" demiştir (Grooteart, 2010: 234-235). Bu bağlamda sosyal sermaye, topluma yön veren ahlaki değerlerle, kültürel yap1 ve eğitimle iç içe kalkınmaya önemli katkılar sunabilmektedir (Karagül ve Masca, 2005: 39).

Sosyal sermaye bireysel ve kolektif getiriler kazandıran özelliklere sahiptir (Ağcasulu, 2017). Sosyal sermaye teorisyenlerinin bazıları bireysel kazanımlara vurgu yaparken diğerleri kolektif kazanımlar üzerinde yoğunlaşmışlardır. Toplum yararına olan pek çok şey sosyal sermayeyi geliştirirken sosyal sermaye de ekonomik ve sosyo-kültürel kalkınmaya katkı sağlayarak toplumun huzur ve refahı için önemli kazanımlar sunmaktadır (Grooteart, 2010: 228). Aslında bu alt yapı olan ekonominin ve üst yapının birbiri ile etkileşim halinde olduğu iddiasındadır. Yani Marx'ın ifade ettiği gibi alt yapının üst yapıyı, Weber'in ifade ettiği gibi üst yapının alt yapıyı şekillendirdiği yaklaşımından farklı bir iddiada bulunmaktadır (Fukuyama, 2010: 165).

Bütün bu ifadelerin sonunda, sosyal sermayenin insanların ortaklaşa hareket etmesini sağlayan normları ve ağları gösterdiğine dair artan bir uzlaşma ortaya çıkmaktadır (Olate, 2003: 10). Bu toplumsal ortak uzlaşma alanı yani farklılıkları ortak bir paydada buluşturma çokkültürcülüğün de hedefleri arasındadır. Yani her iki kavram arasında bir nedensellik bağından söz etmek mümkündür. Her ne kadar her ikisine tam da bu noktada karşıt 
eleştiriler yapılsa da bunların tam tersini gösteren somut örnekler olmadığ1nı ifade etmek gerekir.

Fukuyama sosyal sermayenin modern demokrasilerdeki siyasal işlevini en iyi şekilde Tocqueville'in açıkladığını ifade etmiştir. Tocqueville sosyal sermaye için "birleşme sanatı" kavramını kullanmıştır. Ona göre sosyal sermaye geleneğinden kopan ve bireyselleşen insanları bir araya getirebilecek "vatandaşlık okulu" görevi üstlenmektedir (Fukuyama, 2010: 151-152). Eş deyişle yatay ve dikey karşılıklı güvene dayalı gayri resmi insani örgütlenme türlerinin hepsi zengin bir sosyal hayatın önemli unsurlarındandır. "Yüz arkadaş yüz rubleden daha değerlidir” şeklindeki Rus ata sözü ve Woolcock'un (2003) "sosyal sermaye bildiğiniz şeyler değil tanıdığınız kimselerdir" şeklindeki tanımlaması sosyal güvene dayalı sosyal ilişkilerin önemini veciz bir şekilde vurgulamaktadır (Grooteart, 2010: 235).

Sosyal sermaye ile ilgili çalışmalar özel olarak siyasal ve genel olarak toplumsal hayatın kalitesi ve niteliği ile ilgili gözükmekte ve genel olarak toplumsal bütünleşmenin en önemli unsuru olarak durmaktadır. Bu bağlamda sosyal sermayenin ortaklaşa paylaşılan normlara dayalı, dürüst ve iş birliği yönünde davranan üyelerin oluşturduğu bir toplumda ortaya çıkması beklenir. Bu bağlamada çeşitliliklerin aynı devlet çatısı altında barışçı bir şekilde bir arada olmalarını sağlayacak en önemli iddianın çokkültürcülük olduğu söylenebilir.

\section{Çokkültürccülük}

Farklı kültürlerin bir arada yaşama durumlarının tarihsel bir karşılığı vardır. Bu farklılıkların siyaset teorisinde yer bulması çoğulculuk kavramıyla açıklanmıştır. Ancak kültürel çeşitliliğin hem toplumsal hem de siyasi arenada karşılık bulduğu çokkültürcülük için hem yeni bir kavram hem de yeni teoridir denebilir. Resmi bir hükümet politikası olarak "çokkültürlücülük" için beyaz ve Hıristiyan olmayan ülkelerden akan göçün artması sonucunda, 1960’lar sonu ve 1970’lerde gündeme gelmiştir denebilir (Kymlicka, 1998: 270). Aynı devlet çatısı altında birden fazla kültürün yaşadığı toplumlara çokkültürlü toplum, bu çeşitliliklere verilen felsefi ve politik tepkilereyse çokkültürcülük denmektedir. Çokkültürcülük teorisinin bir devlet bir de toplumsal ayağı bulunmaktadır. Çokkültürlülüğü devlet politikalarıyla desteklemek ve kültürel çeşitliliğe toplumun olumlu bakıyor olmasının karşılığı çokkültürcülüktür.

Bir toplum içinde farklı kültürlerin olması ve bunlara karşı olan farklı bakışlar tarihsel bir gerçekliktir ve J.S. Mill, Humboldt, Herder ve yakın 
zamanda Berlin, Raz ve Kymlicka bunların lehine savunma yapmıştır (Parekh, 2002: 211). Ancak Parekh bunların kültürel eşitliğe yaptıkları katkıları az bulur ve eleştirir. Onlara ek olarak kültürel çeşitliliğin lehine yeni savlar ortaya koyar. Bunlar: 1. Bir kültür ne kadar zengin olursa olsun insanların tüm potansiyellerini geliştirmesi mümkün değildir. Bu yüzden diğer kültürlerden faydalanarak bazı açmazlarımızı gideririz. 2. Kültürel çeşitlilik insan özgürlüğünün önemli bir bileşeni ve şartıdır. Kendi kültürü dışında kültür tanımazsa kendi kültürünü mutlaklaştırır ve insan yaşamını algılamanın tek doğal yolunun o olduğunu sanmaya başlar. 3. Kültürlerin çeşitliliği bizi kendi kültürümüz içindeki çeşitlikten de haberdar eder. 4. Kültürel çeşitlilik, farklı kültürlerin iki tarafa da yararı olacak bir diyaloga girmelerini kolaylaştıran bir ortam yaratır (Parekh, 2002: 214-215). Neticede kültürel çeşitliliğe sahip bir toplum, her açıdan mükemmel olmasa da iyi bir toplumda arzu edilen nitelikler arasında daha iyi bir denge kurma iddiasındadır (Parekh, 2002).

Çokkültürlülük, kimlik ve ötekilik gelişmiş batılı ülkelerin masasında çözüm bekleyen en önemli sorunlardan biri olarak görülebilir (Tekinalp, 2005: 75). Ancak bütün dünyada bunlar üzerinden çıkan tartışmalar ve neticesinde kutuplaşma ve çatışmalar sosyal sermayeyi aşağıya çeken en önemli unsurlardır. Bunlar içerisinde çokkültürcülüğün ulus-devlet kazanımlarına zarar vereceğini en net şekilde ifade edenlerden birinin Habermas olduğu söylenebilir. Bu açıdan Habermas, hem "liberalizm 2" hem de çokkültürcülük teorisinin cemaatçi kanadına ciddi eleştireler getirmektedir (Habermas, 2010: 126-161; Habermas, 2012: 125). ${ }^{2}$ Bu nedenle de Habermas asimilasyoncu olmasa bile Parekh tarafından "sivil asimilasyoncu" olarak tarif edilir (Parekh, 2002: 256). Burada çokkültürcülük teorisyenlerinin düşüncelerinin yaşadıkları devletlerin politikalarıyla benzeştiğini vurgulamak gerekir. Federal Almanya'nın çokkültürcülüğe bakışı sanki Habermas'ta birebir karşılık bulmuş gibidir. Bunu daha pek çok teorisyenin (Kymlicak, Taylor, Parekh, Modood) yaklaşımında görmek mümkündür.

Modern dünyada birçok yaşam tarzı (modus vivendi) kendine yer bulmak istemektedir. Bunu sağlamaya çalışan devletler çeşitli politikalar denemeye çalışmaktadırlar. Bu bağlamda devletlerden, bir arada yaşama kültürünün güvencesi olması beklenmektedir (Habermas, 2012: 133). Bunun genelde vatandaşlara hep aynı gözle bakan (renk körü) liberal bir hukuk sistemiyle mümkün olabileceği savunulur. Birleşik Krallık, Amerika Birleşik Devletleri, Kanada ve Avustralya, İsviçre dışında yapılan çokkültürcülük tartışmalarının genelini

2 Michael Walzer liberalizmi kendi içinde ikiye ayırmaktadır: Liberalizm 1 ve liberalizm 2. Liberalizm 1 'in klasik liberalizmi temsil ettiği, liberalizm 2'nin ise cemaatçilere daha yakın olduğu söylenebilir (Walzer, 2010: 117). 
bu noktada değerlendirebilmek mümkündür. Onlara göre modern hukuk sistemi bireyselcidir ve tek tek her bir kişi öznel hakların taşıyıcısıdır. Bütün bireyleri eşit düzeyde gören hukuk da ancak tüm bireylerin özerkliğini eşit biçimde sağlayabildiği sürece meşrudur (Habermas, 2010: 138; Habermas, 2012: 123). Ancak bu türden devleti merkeze yerleştiren ulus-devlet düzenini ideal olarak gören sistem, ortak değerler, mükemmellik idealleri, ahlaki inançlar ve toplumsal adetler de dahil, ortak bir ulusal kültüre sahip değilse hiçbir yönetim biçiminin istikrarlı olmayacağını savunur (Parekh, 2002: 252).

Klasik liberal bakış açısına göre kimliklerin ve inançların kamuda tanınması ve saygı görmesi toplulukçu anlamda karşılık bulmak yerine bireysel bazda herkese tanınan haklar çerçevesince düzenlenmelidir. Yani bu tanıma göre tanınan haklar bireylerin haklarını ihmal etmemeli ve başkalarına zarar vermemelidir (Modood, 2014: 98). Bazı kolektif hakların bireysel haklar1 tehdit edebileceğine dair kuvvetli bir kanı vardır (Parekh, 2002: 276) ve bazı somut örnekler bu kanıyı haklı hale getirmektedir. Mesela Kanada Quebec'te çocukların gönderileceği okulların önceden belirlenmesi, sözleşmelerin Fransızca olarak hazırlanmak zorunda olması gibi şeyler bireysel hakların ötesinde olan şeylerdir (Taylor, 2010: 75). Ancak genel olarak ifade etmek gerekirse, bir kültürel topluluk insan kıymeti ve itibarına saygı duymuyorsa, temel insan çıkarlarını kanyakları dahilinde korumuyorsa, yabancılar için tehdit oluşturuyorsa, çoğu üyesinin sadakatine sahip değilse ve böylece temel iyi yaşam koşullarını sağlamıyorsa kendisine saygı gösterilmesini ve rahat bırakılmayı hak etmemektedir (Parekh, 2002: 227). Bir azınlık kültürün kendi üyelerinin temel medeni ya da politik özgürlüklerini kısıtlama hakkının olmaması gerektiğini Kymlicka "iç kısıtlamalar" olarak ifade etmektedir (Kymlicka, 1998: 234-235).

Devletin tarafsız olması (renk körü), sistemin toplulukçu değil bireyselci olması, devletin etik ve dinsel hiçbir görüş bildirmemesi ancak makul görüşler karşısında tarafsızlığını koruması gerektiği klasik liberal görüşün savıdır. Rawls'un adalet teorisi bunun en iyi örneklerindendir. Liberallerin bütün bu savlarını Nathan Glazer'in ifadesiyle "iyi niyetli ihmal” şeklinde okumak mümkündür (Kymlicka, 1998: 29). Rawls'un ifade ettiği “makul görüş” her ne kadar "makul” olanın diğer görüşlerden üstünlüğü olamasa da (Modood, 2014: 94) kaçınılmaz olarak baskın olanların görüşleri olacaktır ve hali hazırda bunun pek çok örnekliği mevcuttur. Eş deyişle, hiçbir ahlaki talepte bulunmayan, tüm kültürlere aynı hoşgörüyü gösteren, ahlaki ve kültürel açıdan zorlayıcı olmayan bir devlet düşünmek zordur (Kymlicka, 1998: 31, 96; Parekh, 2002: 258, 283; Walzer, 2010: 119). Yani klasik liberalizmin savunduğu “iyi niyetli ihmal” fikri tutarsız gözükmektedir. Bu nedenle liberal değerlerin 
istediği türden ortak bir "iyi” belirlemeyen bütün kültürlere karşı yansız bir devlet anlayışı realiteye ters düşmektedir.

Liberalizmin en temel taahhüdü, "birey olarak yurttaşlar özgür ve eşittir"dir (Kymlicka, 1998: 71). Liberal bakış açısındaki "kendi” anlayışına göre, birey toplumsal uygulamalara katılım konusunda özgürdür ve bu uygulamaların gereksizliğine karar verirse, bunları yerine getirmeyebilir (Kymlicka, 2006: 225). Bu savın nedeni, seçimi yapan bireyin bireysel özerkliğine sayg1 duymamız gerekliliğidir (Tok, 2003: 14-15). Bu bağlamda kişi hakları sağlam bir temele kavuşturulduğunda azınlık hakları bağlamında yeni bir haklar çerçevesine gerek kalmayacaktır (Kymlicka, 1998: 29). Kısacası bireyciler "bireyin ahlaki bakımdan cemaatten önce geldiğini savunur: Cemaat ancak kendisini oluşturan bireylerin refahına katkıda bulunduğu için önemlidir”. Buna karşın kolektivistler ise cemaat haklarının, cemaati oluşturan bireylerin haklarından önce gelmesi gerektiğini savunurlar (Kymlicka, 1998: 90; Taylor, 2011). Çünkü onlara göre insan zihninin doğuşu monolojik değil, aksine diyalojik bir şeydir (Taylor, 2010: 53). Cemaatçiler liberallerden farklı olarak ortak bir iyi kavrayışı peşindedirler. Bu tek tek üyelerinin haklarını sınırlandırıyor bile olsa ortak değerlerin oluşturulabileceği “ortak iyi politikası" geliştirmek isterler (Kymlicka, 1998: 151). Bu ölçüde her kültürün “eşit” ölçüde saygıdeğer kabul edilmesi gerektiğini savunurlar.

Çokkültücülüğün asıl iddiası, yurttaşlığın ve ulusal kimliğin yeniden tanımlanması suretiyle, paylaşılan ortak yönleri, farklılıkları görmezden gelmeden vurgulayabilecek bir ortaklık vizyonu oluşturabilmektedir. Bu politikanın amacı "farklılıkları görmezlikten gelme” yerine ayrıcı özellikleri gözetmek ve korumaktır. Onlara göre sonuçta ortaya çıkan durum ayrımcılığı destekler çıktılar vermez (Taylor, 2010: 60). Bu anlamılla çokkültürcülük toplumsal bütünleşme ve etkileşim biçimlerini teşvik eden, grup kimliklerinin normatif ve siyasal açıdan öneme sahip olduklarını kabul eden bir sivil etkileşim biçimi olarak okunabilir (Modood, 2014: 95). Bu haliyle çokkültürcülüğün oluşabilecek sosyal sermayeye katkı sağlaması ve her ikisinin toplumsal bütünleşmeye zemin hazırlaması beklenebilir.

Çoğu liberal tarafından topluluklar eğer hak sahibi olurlarsa bunları kötüye kullanabilecekleri ve bireysel hakları tehdit edebilecekleri yönünde iddia ileri sürülmektedir. Bu haklar toplumu bir arada tutan ortak yurttaşlık duygusunu zayıflatacak, hatta ülkenin dağılmasına yol açabilecek kadar ileri seviyede olmasa bile toplum içerisindeki karşılıklı fedakârlık ve toplumsal bütünleşmeyi zayıflatacak, bölünmeye kaynaklık edecektir (Kymlicka, 1998: 73, 264). Ancak çokkültürcülük teorisyenlerinin hak iddiaları ayrışmayı değil, 
halkları ortak değerler etrafında buluşturabilmek ve bütünleşmeyi ilerletmek için vardır. Çokkültürcülük teorisyenlerinin çoğunun çalışmalarında (Charles Taylor, Will Kymlicka, Bhikhu Parekh, Anne Phillips, Tariq Modood) ve Kanada, Avustralya ve Britanya gibi ülkelerin belgelerinde ortaya çıkan çokkültürcülük, bütünleşmeyi hedeflemektedir (Modood, 2014: 237). Bütün halklar1 ortak değerler etrafında buluşturan bütünleşme, iki uçlu bir süreçtir. Hem baskın kültürü hem de göçmenleri karşılıklı uyarlamayı gerektirir. Bu türden bir bütünleşme ön yargı ve ayrımcılıkla mücadele etme noktasında her iki taraftan da güçlü gayretler bekler (Kymlicka, 1998: 158).

\section{Toplumsal Bütünleşme Bağlamında Çokkültürcülük ve Sosyal Sermaye Savunusu}

Tarih boyunca devletler çeşitliliklere karşı çok çeşitli politikalar izlemişlerdir. Çokkültürlü yapıya karşı iki türlü yaklaşımdan söz edilebilir. Birincisi çokkültürlülüğü reddetmek ve egemen kültürün dışındakileri egemen kültürün lehine asimile etmektir. Bunun için farklı yöntemler kullanmışlardır. Kitlesel sürgün, soykırım, fiziksel tecrit ve ekonomik ayrımcılık bunlardan bazılarıdır (Kymlicka, 1998: 27). İkincisi ise bütün kültürleri kabul edip onlara karşı hoşgörülü davranmaktır. Birinci durumda ortaya konan politikalar asimilasyon ve entegrasyon, ikinci durum ise çokkültürcülük olarak kavramsallaştırılmaktadır. Birinci durumda çatışma, kutuplaşma ve ötekileştirme söz konusudur ve bu durum toplumsal bütünleşmeyi ve sosyal güveni azaltıcı özelliklere sahiptir. Bu haliyle birinci seçenek istenmeyen ve nerdeyse imkânsız bir süreçtir (Parekh, 2002: 220).

Çokkültürcülük hem toplumsal hem de politik bir tavır alma şeklidir. Yani hem toplumun hem de siyasi iradenin kültürel çeşitliliğe hoşgörülü ve olumlu bakması gerekir. Sosyal sermaye savunucularının ileri sürdükleri şeylerden bir tanesi devlet ve toplum arasında "köprü kuran" bir özelliğe sahip olmas1dır. Sosyal sermayeye karşı olumsuz sonuçlar doğuran belli başlı nedenler arasında sayılan iktidar seçkinleri ve aydınlar ile halk arasındaki uçurum, sosyal sermayenin kuracağı kurumsal güven köprüsüyle ortadan kaldırılmış olur. Çünkü insanların birbirlerine, kurumlara ve aydınlara olan güvenleri kolektif bir bütünleşmeye hizmet edebilir özelliğe sahiptir. Bu tür durumlarda devlet ve toplum birbirini tamamlar; refah ve toplumsal düzen büyük ihtimalle sağlanır (Woolcokc ve Narayan, 2000: 237). Ancak iyi işlemeyen homojen toplumlarda dahi bunun tam tersi bir çatışmanın olması da muhtemeldir.

Daha çok kalkınma hedefleri bağlamında değerlendirilen sosyal sermayenin büyüme, eşitliği sağlama, yoksulluğu ve adaletsizliği azaltma noktasında 
etkili olduğuna dair yaklaşımlar mevcuttur. "Sosyal sermaye ne kadar fazla yayılırsa, eşitliğin oluşturulmasına o kadar katkı sağlayacaktır” (Grooteart, 2010: 239). Toplumsal güven, hukukun üstünlüğü, insan hakları ve bürokrasinin kalitesi gibi unsurlar, kalkınmaya pozitif yönde etki ederken, yolsuzluk, bürokratik engeller, baskı altına alınmış insan hakları, eşitsizlik, etnik gerginlikler, korunmayan mülkiyet hakları refah seviyesinin önündeki en büyük engeller olarak görülmektedir (Woolcock ve Narayan, 2000: 234-235). Sosyal sermayenin en önemli unsurlarından olan sivil toplum, bireyler arasında güven ve karşılıklılık üzerine inşa edilerek yoksulluğun, eşitsizlik ve adaletsizliğin azaldığı daha sağlıklı ve bütünleşik bir topluluk oluşturmaya imkân tanıyacaktır.

Çokkültürcü bir toplum oluşturma hedefi adına yapılan ortak çokkültürlü bir kültür, herkesin fikir birliğine vardığı bir otorite, anayasal bir hak, adil ve tarafsız bir devlet, çokkültürlü bir eğitim, kapsayıcı ulusal bir kimlik, vatandaşlar arasında ortak bir aidiyet gibi bütün koşullar sosyal sermayeyi yükseltecek şeylerdir (Parekh, 2002). Kurumlar ve insanlar arasında demokratik koşullar çerçevesinde bir uzlaşı yaratmak çokkültürcülük politikasının temel gayesidir. Bunun çıktıları olan karşılıklı güven, yardımlaşma ve dayanışma, bunları sağlayan sosyal ağlar ve sivil topluma katılım ise sosyal sermeye olarak ifade edilebilir.

Çokkültürlü ortak bir kültür, farklı topluluklarla buluşup, kültürel, ekonomik ve daha birçok çıkarı rahat bir temelde izleyebilmeleri için yeterli fırsatlar sunan, gelişmekte olan bir sivil toplum gerektirir. Bu bağlamda ortaya çıkan amaçlar kültürleri birbirine alıştırır, kültürler ötesi anlayış ve güveni artırır, çözülmesi noktasında zorlandıkları sorunları aşma ve onlarla beraber yaşama becerileri kazandırır (Parekh, 2002: 284). Ortak bir proje etrafında kenetlenmiş genel iradenin bir üyesi olarak "ben” olmuş bir "biz" ve "biz" olmuş bir "ben” karşılıklı birbirini tanıyan toplumların amacıdır (Taylor, 2010: 68-70).

Çokkültürcü bir toplum hem çeşitliliğin hem de birliğin değerini kabul etmek ve aralarında tatmin edici bir ilişki kurmak durumundadır (Parekh, 2002: 264). Bu bağlamda azınlık haklarının yanında olmak, özgürlük ve adalet ilkesiyle çelişmeyen fikirler ortaya atmakla birlikte demokrasinin gereği karşılıklı saygı, uzlaşma ve fedakârlık düzeyini tutturabilecek ortak bir yurttaşlık kimliği oluşturabilmek de önemlidir (Kymlicka, 1998: 265). Öncelikle baskıdan, kutuplaşmadan, şiddetten, dahası dinsel, etnik ve kültürel çatışmalardan kaçınmanın yolu ortak bir dayanışma kültürünü ve toplumsal bütünleşmeyi gerektirir. Bu çerçevede ortaya çıkan çokkültürcü toplum, karşıllklı güvenin yüksek olduğu sivil toplum için gerekli şartları karşılama adına 
adım atıyor demektir. Yani sosyal sermayenin güçlü olduğu bir toplum olma olasılığı kuvvetle muhtemeldir.

Sosyolojik bir gerçekliktir ki günümüzde neredeyse hiçbir devlet ve toplum kendi içinde homojen değildir (Kymlicka, 1998: 25; Parekh, 2002: 171). Küreselleşme, göçler, ulus-ötesi kurumlar neticesinde oluşan dünyada kendi içine kapanmak neredeyse imkânsız hale gelmiştir. Bu durum bir problemmiş gibi dursa da aslında bir bütün olarak toplum için arzu edilebilir ve değerli bir toplu erdemi temsil edebilme durumu söz konusu olabilir (Parekh, 2002: 252). Çokkültürlü bir toplumda herkesi tek türden bir kültür ve değerler manzumesinde buluşturmak zor olduğu gibi toplumun da bunların hepsini hoş görmesini beklemek zordur. Ancak Putnam'ın sosyal sermaye ayrımında ifade ettiği köprü oluşturan sermaye (Bridging Social Capital) türü çeşitli toplum grupları arasında iş birliğini geliştiren özelliğe sahiptir (Putnam, 2010). Yani kültürel çeşitliliğe sosyal demokrat eşitçilik çerçevesinde muamelede bulunan toplulukların refah seviyelerinin, birlikte yaşama kültürünün, toplumsal dayanışmanın ve karşılıklı güvenin yüksek olduğu söylenebilir. Çokültürcülük teorisi genel manada tek bir kültür ve insan mükemmeliyeti modelini dayatmama iddiasındadır (Parekh, 2002: 221).

Çokuluslu devletlerin içkin olarak istikrarsız olması doğaldır. Ancak bunları reddetmek de bir o kadar sakıncalı olabilir. Çokuluslu bir devlette "ortak yurttaşlık” denen şey aslında çoğunluğun kültürünü desteklemekten başka bir şey değildir (Kymlicka, 1998, 277-278). Bu bağlamda kendilerini ayrı uluslar olarak gören azınlıklara ortak yurttaşlık dayatmak, çatışmayı muhtemel hale getirecektir (Kymlicka, 1998, 279). Farklı bir deyişle, sağlıklı demokratik bir toplum oluşturmanın yolu diğer kültürü tanımaktan geçebilir. Bunun tersine bir durumda ise çeşitliliği reddeden de zarar görebilir (Taylor, 2010: 57). Sonuçta toplumda hedeflenen teklik gerçekleşmediği gibi toplumsal huzur, dayanışma ve bütünleşme de yara alır.

Azınlıkların kimliklerinin bastırılmasına dair yapılan pek çok şeyin gerçekte çok da karşılık bulmadığı söylenebilir. Bastırılmaya çalışılan kimlikler varlıklarını hâlâ korumakta ve bu durumun devamlılığı probleme ve kutuplaşmaya neden olmaktan öteye gitmemektedir. "Eğitimde ve medyada tam bir tekel kurmuş olmalarına rağmen, Komünist rejimler Hırvatların, Slovakların ve Ukraynalıların kendilerini öncelikle "Yugoslavlar, Çekoslovakyalılar” ya da "Sovyetler" olarak düşünmelerini sağlayamamıştır. Ulusal kimliklerin yerine geçecek "pan-hareketler" oluşturma-örneğin, pan-Slav ya da pan-Arap devletler yaratma- gayretlerinin aynı şekilde boşuna oldukları belli olmuştur" (Kymlicka, 1998: 280). Bu durumda çeşitlilikleri yok etmeye çalışmak yerine onları 
hoş görmek daha sağlıklıymış gibi durmaktadır. Öyle ki bazı çalışmalarda çeşitliliğin bir güç olarak algılandığı ortaya çıkmıştır. Bu anlamda bazı sosyal sermaye ölçüm çalışmalarında "çeşitliliği hoş görme" bir gösterge olarak kendine yer bulmuştur (Woolcock ve Narayan, 2000: 241). Neticede toplumsal bütünleşmenin sağlanmasında çokkültürcülüğün en önemli iddialarından olan farklılıkları "hoş görme” sosyal sermaye için de önemli bir göstergedir.

Kymlicka çoketniklilik hakları bağlamında temsil unsurunun dışlanan insanların topluma olan aidiyet hissini güçlendireceğini savunur $(1998,268)$. Ona göre, "temsil hakları altında yatan temel dürtü ayrılık değil, bütünleşmedir” (Kymlicka, 1998: 269, 272). Bu haklar, tarihsel önyargıların önüne geçebileceği gibi ileriye dönük güven duygusunu da geliştirebilir. Bu da gelecek kaygısı ortadan kalkmış ve güven indeksinin yüksek olduğu bütünleşmiş bir topluluk oluşturmaya hizmet edebilir.

\section{Toplumsal Bütünleşme Bağlamında Çokkültürcülük ve Sosyal Sermaye Eleştirisi}

Tartışmalardan uzak ve herkes tarafından kabul bulmuş bir çokkültürcülük teorisinden bahsetmek zordur. Çokkültürcü olduğunu iddia eden pek çok devlet ve toplum bu konuda ciddi tartışmalar içerisindedir. Çokkültürcülüğe dair yapılan eleştirileri altı başlık altında toplamak mümkündür: Birincisi, modern ulus-devletin zarar göreceği yönündeki eleştiriler, ikincisi, çokkültürcülüğün yeni ırkçı söylem olduğu yönündeki eleştiriler, üçüncüsü, küresel kapitalizmin yeni oyuncağı olduğu şeklindeki eleştiriler, dördüncüsü, çokkültürcülüğün bir mit olduğu yönündeki eleştiriler, beşincisi, çokkültürcülüğün yeni bir asimilasyon olduğu yönündeki eleştiriler, altıncısı ise, çokkültürcülüğün hedefine ulaşamadığı yönündeki eleştirilerdir (Şan, 2006; Zizek, 2011; Anık, 2012). Bunlar içinde bu çalışma bağlamında en dikkat çekici eleştirilerin ilk iki eleştiri olduğu söylenebilir. Birincisi modern dönemde toplulukları ortak bir paydada buluşturma adına ortaya çıkmış olan ulus-devletin zarar göreceği yönündeki eleştiri, diğeri ise yeni bir ırkçllık türü olması şeklindedir. Birlikte yaşama, ortak bir paydada buluşturma ve istikrarlı bir barış iddiasıyla ortaya çıkan çokkültürcülük aslında bunların aleyhine olmakla suçlanmaktadır (Modood, 2014: 217). Yani bu eleştirilerin ortak iddiası, çokkültürcülüğün bütünleşmeye zarar verdiği yönündedir. ${ }^{3}$

Sosyal sermaye kavramı çerçevesinde yapılan tartışmalarda da sosyal sermayenin hem lehine hem de aleyhine yaklaşımlar mevcuttur. Yani sosyal

3 Bu konuda bkz. Roccefeller, 2010. 
sermayenin pozitif sonuçları olduğu gibi negatif sonuçları olduğu da söylenebilir (Woolcock ve Narayan, 2000: 225; Fukuyama, 2002: 29; Fine, 2010: 315316). Bu açıdan sosyal sermaye pek çok açıdan eleştiriye tabi tutulmaktadır (Beşer ve Hira, 2017). Mesela sosyal sermaye için kaynaklık eden din, her zaman pozitif veriler üretmeyebilir. Din savaşları, mezhepçilik ve bunun neticesinde ortaya çıkan hoşgörüsüzlük ve şiddet bunun örneklerindendir (Fukuyama, 2002: 169; Berger, 2006: 394). Coleman "sosyal sermayenin belli bazı eylemleri kolaylaştıran bilinen bir biçimi başkaları için kullanışsız hatta zarar verici olabilir" demektedir (Grooteart, 2010: 226). Benzer şekilde Bourdieu da sosyal sermayenin toplumsal eşitsizliğin ve elitler iktidarının devamlılığına aracı olabileceğini savunmaktadır (Yarc1, 2011). Özellikle İtalya için verilen örneklerde kendi içinde oluşturulmuş dışarıya karşı güvensizliğin çokça taraftar bulduğu mafya mantığı, sosyal sermayenin karanlık yüzü olarak okunabilir.

Fiziksel sermayeyi yok eden, ekonomiyi çökerten, insan sermayesini bozan ve sosyal sermayeyi eriterek sosyal uyumsuzlukların en yıkıcı biçimlerinden birinin etnik çeşitlilik olduğu söylenebilir. Etnik karmaşa neticesinde ortaya çıkan çatışmalar ve siyasal istikrarsızlık sürdürülebilir bir kalkınmanın önüne geçen en önemli nedenler arasında sayılabilir (Grooteart, 2010: 253; Habermas, 2010: 135). Aynı şekilde bu durum dinsel, ırksal ve kültürel çeşitlilik için de ifade edilebilir. Zaten çokkültürcülüğe yapılan pek çok itirazın temelinde farklılaşmış yurttaşlığa tanınan toleransın sürdürülebilir birlik ve bütünlüğe zarar vereceği iddiası yatmaktadır (Konuralp, 2018: 144).

Farklılaşmış yurttaşlık fikrinin daha en baştan eşit yurttaşlar fikrine zıt olduğu iddiası genel bir kanıdır. Bunu savunanlara göre bütüne değil de farklılıklara odaklanılırsa Glazer'in ifade ettiği gibi “tüm Amerikalıların daha derin kardeşlikleri umudu terk edilmek zorunda kalınacaktır” (Kymlicka, 1998: 266-267). “Artık hiçbir şey çeşitli grupları toplum içinde bir arada tutamayacak ve karşılıklı güvensizlik ya da çatışmanın yayılmasını önleyemeyecektir. Yurttaşlık eğer farklılaşırsa, artık ortak bir deneyim ya da ortak statü temin edemez. Yurttaşlık artan sosyal farklılaşma karşısında birliği beslemenin bir yolu olmak yerine, bölünmenin bir başka gücü haline gelecektir" (Kymlicka, 1998: 267).

Sosyal sermaye oluşturma noktasında çoğulcu bir toplumdansa homojen bir toplumun avantajlarının daha çok olduğu söylenebilir. Homojen bir toplumun sosyal sermaye açısından güçlü yönleri vardır. Homojen olma durumu, "topluluk ve dayanışma hissini güçlendirir, kişiler arası iletişimi kolaylaştırır, kültürün devamlılığını sağlar, bir arada tutması görece daha kolaydır, psikolojik ve politik bakımdan ekonomiktir, üyelerin bağlılığına güvenebilir ve bu 
bağlılığı kolaylıkla harekete geçirebilir" (Parekh, 2002: 170). Hatta çokuluslu yani homojen olmayan devletlerin doğal olarak istikrarsız (Taylor, 2010: 84) ve bu yüzden otoriter bir yönetime mahkum olacakları iddiası vardır (Kymlicka, 1998: 95, 265). Kanada Quebec, İspanya Katalonya, Büyük Britanya İskoçya gibi ayrılıkçı tartışmaların homojen ol(a)mamadan kaynaklandığı söylenebilir. Ancak homojen olan toplumların her durumda sosyal sermayelerinin güçlü olduğuna dair somut örnek bulmanın zor olduğunu da ifade etmek gerekir.

Etnik, dinsel ve ırkçı gruplar arasında ortaya çıkan ve genellikle şiddetle sonuçlanan ayrılıklar çeşitliliğin aleyhine sonuçlanmaktadır. Çeşitliliği bir zenginlik olarak görebilmek ve ondan faydalanacak noktaya gelmek pek çok şartı ve koşulu içinde barındırmaktadır. Dinsel, dilsel, etnik birbirini dışlayan ve saygı duymayan çeşitlilikler çokkültürcülüğün vaadiymiş gibi algılanabilmektedir. Siyasal çokkültürcülük bağlamında tartışılan yamyamlık, dul kadının ölen kocasıyla birlikte yakılması (sati), kadın sünneti ve buna benzer pek çok şey bireyin temel haklarını ihmal edecek veya başkalarına zarar verecek türden şeyler bunlar arasında sayılabilir. Bu haklar bağlamında savunulanların dışına çıkabilecek türden istisna olabilecek kötü örneklerin genellemesi yapılabilmektedir. Bu türden istisnai durumlar çokkültürcülük ekseninde tartışılmakta ve çokkültürcülüğe mal edilebilmektedir (Modood, 2014: 98).

Yukarıda çokkültürcülüğün bütünleşme yanlısı hareket ettiği ifade edilse de Kymlicka’nın (1998: 275) azınlık “ulus”lar için ifade ettiği özyönetim hakları "yurttaşlığın bütünleştirme işlevine çok ciddi bir meydan okuyuştur”. Cemaatçilerin topluluklara tanıdığı Kymlicka'nın “iç kısıtlamalar” olarak ifade ettiği ama karşı çıktığı cemaat hakkı Fukuyama’nın bir grubun kendi içinde oluşturduğu sosyal sermaye indeksi olan güvenin dişarısı için geçerli olmaması tezini destekler niteliktedir. "Çin ve Güney İtalya gibi aile bağlarının güçlü olduğu toplumlar, ailenin dışındakilere yönelik genellenmiş sosyal güven eksikliği ile tanımlanmıştır” (Fukuyama, 2010: 159). $\mathrm{Bu}$ da dışardakilere yönelik güvensizlik, hoşgörüsüzlük, nefret ve neticede şiddet üretebilir. Bu bakış açısı üzerine kurgulanmış bir devlette genellikle özgürlüğün, demokrasinin, refahın, hukuka saygının ve sosyal sermayenin yüksek olduğunu söylemek zordur ve bu durumda toplumsal bütünleşme olgusu ciddi zarar görmektedir. Çokkültürcülüğün ve sosyal sermayenin toplumsal barışı sağlayabilmiş toplumlarda bir korelasyon içinde olduğu göstergeler bulabilmek mümkündür. 


\section{Sosyal Sermaye ve Çokkültürcülük İlişkisine Dair Göstergeler}

Sosyal sermayeye karşı olumsuz sonuçlar doğuran belli başlı nedenler arasında şunlar sayılabilir: Etnik çatışma, yoksulluk ve eşitsizlik, iktidar seçkinleri ve aydınlar ile halk arasındaki uçurum, devletin merkeziyetçi bir yapı sergilemesi ve halkın inancı ve kültürüyle çatışması (devlet-yurttaş çatışması), halkın demokratik unsurlarla yeteri kadar iştigal olmaması. Bunlar arasında toplumun sosyal sermayesini aşağıya çeken en önemli şeyin etnik çatışma kaynaklı ırkçılık olduğu söylenebilir. Çünkü ırkçılık, halihazırda etnik çatışmaların en önemli nedeni olarak gözükmektedir. Irkçılığın topluluklar arası çatışmalara, geçmişte yaşanmış gerçek veya hayali haksızlıkların anılarına dayandığı söylenebilir. Aslında ırkçılık farklı ırkların aynı devlet çatısı altında birlikte yaşayamamalarının bir sonucudur. Etnik ve kültürel çeşitlilik, potansiyel olarak ayrılıkçı pek çok sorunu bünyesinde taşımaktadır (Kymlicka, 2012: 11). Dilsel haklar, federalizm beklentisi, siyasi temsil, müfredat, vatandaşlık, ulusal marş, resmî tatiller gibi pek çok şey ekseninde çıkan etnik ve kültürel çatışmalar ve kutuplaşmalar şiddetin en yaygın kaynağı olma durumuna gelmiştir (Kymlicka, 1998: 26). Çokkültürcü bir toplumun en önemli hedeflerinden birisi çeşitlilik merkezli bu çatışmaları hızla, adil ve insancıl bir biçimde çözmektir (Parekh, 2002: 271). Bu bağlamda sorunlu ve tartışmalara açık olduğu halde çokkültürcülüğün temelde hedeflediği şey istikrarlı bir barıştır.

Görüleceği gibi sosyal sermayeyi olumsuz etkileyen unsurların neredeyse tamamı çokkültürcülük aleyhine de oluşan durumlar gibi durmaktadır. Bunların ortadan kalkması adına iddiada bulunan çokkültürcülüğün hedefine ulaşması durumunda ortaya çıkan sonuç, sosyal sermayesi yüksek olan bir toplum olacaktır. Bu açıdan yukarıda birçok kez değinildiği gibi her iki kavramın ortak paylaşımlara sahip olduğu söylenebilir. Kesler ve Bloemraad'ın on dokuz ülkede yaptıkları çalışmada çokkültürcülük politikalarının politik katılım ve sosyal sermaye üzerinde olumlu katkısı olduğu anlaşılmıştır (Kesler ve Bloemraad, 2010). Aynı şekilde Güleç (2019) tarafından yapılan çalışmada sınıf öğretmenlerinin sosyal sermaye yeterlilikleri ile çokkültürlü eğitime yönelik tutumları arasında pozitif ve orta düzeyde anlamlı ilişki tespit edilmiştir.

Geçerliliği noktasında ciddi eleştirilere tabi tutulsa da ülkelerin sosyal sermayesini ölçen göstergeler mevcuttur. Bu bağlamda çok farklı göstergelerden bahsedilebilir (Grooterat, 2010: 249-251; Putnam, 2010; Fukuyama, 2010). Ancak bu göstergeler içinde genel kabullerin şunlar olduğu söylenebilir: Güvenin ölçülmesi, toplumun örgütsel yaşamının ölçülmesi, siyasal karar alma sürecine katılımın ölçülmesi, toplumsal gönüllülüğün ölçülmesi ve enformel sosyalliğin ölçülmesi. Ancak bunlar içinde en dikkat çekici 
olanı Grootaert, Narayan, Jones ve Woolcock gibi sosyal sermaye literatürünün önemli isimlerinin hazırlamış olduğu Dünya Banka’sının göstergeleridir. Dünya Banka'sının göstergeleri arasında Gruplar ve Ağlar, Güven ve Dayanışma, Ortak Eylem ve İş birliği, Sosyal Bağlılık, Bilgi ve İletişim bulunmaktadır (Büyükilikmen, 2015: 51). Bu göstergeler sayesinde bir ülkenin sosyal sermayesinin ölçümü yapılabilmektedir. Her ne kadar göstergeler her ülkede aynı oranda karşılık bulamasa da sonuçların ülkeler adına bize bazı somut örnekler sunduğu bilinmelidir. ${ }^{4}$ Sosyal sermayenin ölçülmesi noktasında güven indeksi göstergesinin pek çok kişi ve kurum tarafından dikkate alındığını özellikle belirtmek gerekir. Çünkü sosyal sermaye çalışmalarında sosyal sermaye düzeyi genellikle güven analizi üzerinden oluşturulmuştur (Tecim, 2011: 34). Öyle ki güven düzeyinin yüksek olması sosyal sermayenin de yüksek olduğunun göstergesi olarak kabul edilmiştir (Putnam, 1993). ${ }^{5} \mathrm{Bu}$ açıdan aşağıda çokkültürcülük indeksi yüksek olan bazı ülkelerin güven indeksine dair sonuçları verilmiştir.

Tablo 1: Kişilerarası Güven. Most people can be trusted “Çoğu insana güvenilebilir”. Aileye Güven (How much do you trust your family?).

\begin{tabular}{|l|c|c|}
\hline Ülkeler & Kişilerarası Güven İndeksi & Aileye Güven \\
\hline Avusturalya & 48.5 & 77.2 \\
\hline Birleşik Krallık & 29.96 & 85.0 \\
\hline Finlandiya & 57.99 & 90.2 \\
\hline Kanada & 41.11 & 82.6 \\
\hline İsveç & 63.7 & 88.8 \\
\hline Norveç & 73.73 & 90.4 \\
\hline Yeni Zelenda & 56.6 & 78.4 \\
\hline
\end{tabular}

(World Values Survey wave 5 (2005-2009), wave 6 (2010-214) and wave 7 (2017-2020).

$\mathrm{Bu}$ tabloda veriler verilirken üç dalganın sonuçlarından yararlanılmıştır. Çünkü Dünya Değerler Araştırması farklı tarihlerde ülkelerin analizlerini güncellemeyebiliyor. Örnek olarak Avusturalya ve Yeni Zelanda verileri 7. dalgaya aitken, İsveç'in verileri 6. dalgaya, Finlandiya, Kanada, Birleşik Krallık ve Norveç'inki ise 5. dalgaya aittir. Tabloda görüleceği üzere en yüksek kişilerarası güven indeksi Norveç ve İsveç’te çıkmıştır. Onları sırasıyla Finlandiya, Yeni Zelenda, Avusturalya ve Birleşik Krallık takip etmektedir.

4 Türkiye özelinde sosyal sermayenin göstergelerine ve ölçümüne dair eleştirilerin olduğu bilinmelidir. Konu hakkında bkz. Şan ve Akyiğit, 2015.

5 Güven indeksi alınırken Tablo 1'de olduğu gibi tek bir soru üzerinden sosyal sermaye analizi yapılmaktadır. Fukuyama (2009) genellikle tek soru üzerinden güven analizi yapılamasını eleştirmiştir. 
Aileye güven konusunda en yüksek olan ülke Norveç, sonda Finlandiya ve ardından sırasıyla İsveç, Birleşik Krallık, Kanada, Yeni Zelenda ve Avusturalya olmuştur. Görüleceği üzere kişilerarası güvenle aileye güven verileri arasında bir çelişki var gibi durmaktadır. Ancak kesin olmamakla birlikte verilerin farklı yıllara ait olmasından böyle bir sonuca varıldığı söylenebilir.

Banting ve Kymlicka'nın bir ülkenin çokkültürcü olduğuna dair belirledikleri göstergeler arasında şunlar sıralanmıştır: Çokkültürlülüğün anayasal, yasal ya da parlamento tarafından güvenceye alınması, okullarda çokkültürlülüğe uygun müfredat hazırlanması, medyada etnik grubun temsilinin adil sağlanması, kıyafet kurallarından azınlık grubun muaf tutulması ya da pozitif ayrımcılık, çifte vatandaşlığa izin verilmesi, etnik grup organizasyonlarının ya da aktivitelerinin maddi olarak desteklenmesi, iki dilli eğitimin ya da anadil eğitiminin finanse edilmesi, dezavantajlı göçmen gruplara karşı olumlu yaklaşım içinde olunmasıdır (Banting ve Kymlicka, 2006). Her bir sekiz politik davranışın karşılığında evet ise 1 puan, nispeten ise 0.5 , hayır ise 0 puan verilmektedir. Tablo 2'deki puanlama cetveli buna göre değerlendirilmiştir.

Tablo 2: Göçmen Azınlıklar için Çokkültürcülük İndeksi, 1980-2000-2010.

\begin{tabular}{|l|c|c|c|}
\hline \multirow{2}{*}{} & \multicolumn{3}{|c|}{ Tanınan sekiz hak üzerinden yıllara göre değerlendirme } \\
\cline { 2 - 4 } & $\mathbf{1 9 8 0}$ & $\mathbf{2 0 0 0}$ & $\mathbf{2 0 1 0}$ \\
\hline Avusturalya & 4 & 8 & 8 \\
\hline Birleşik Krallık & 2.5 & 5.5 & 5.5 \\
\hline Finlandiya & 0 & 1.5 & 6 \\
\hline Kanada & 5 & 7.5 & 7.5 \\
\hline İsveç & 3 & 5 & 7 \\
\hline Norveç & 0 & 0 & 3.5 \\
\hline Yeni Zelanda & 2.5 & 5 & 5.5 \\
\hline
\end{tabular}

(Kymlicka, 2012).

Bu tabloda yukarıda (tablo 1) güven indeksi verilen ülkelerin “Göçmen Azınlıklar İçin Çokkültürcülük İndeksi”ne yer verilmiştir. Tablo 2'de de görüleceği üzere İsveç, Yeni Zelenda, Avusturalya, Finlandiya, Kanada ve Birleşik Krallık'ta çokkültürcülük değerlerinin yüksek olduğu görülmektedir. Yukarıda tablo 1'de verilen veriler arasında İsveç, Yeni Zelenda, Finlandiya, Kanada, Norveç ve Avustralya'nın aynı zamanda kişilerarası ve aileye güven indeksinin de 
yüksek olduğu görülecektir. Yani Birleşik Krallık ve Norveç dişında diğer ülkelerin hem çokkültürcülük hem de sosyal sermaye indeksleri yüksek çıkmıştır. Birleşik Krallık'ın güven indeksi 29.96, Norveç'in çokkültürcülük indeksi yıllara bağlı olarak sırasıyla 0, 0 ve 3 olarak görülmektedir. Ancak her iki ülkenin de iki veri türünün çok kötü olmadığı söylenebilir. Ya da sadece bu alanda değil ekonomik gelişmişlik, demokrasi seviyesi, kurumlara güven, hukuka saygı, sivil hak ve özgürlüklerin makro düzeyde dikkate alınması gerekebilir. Ancak bu ülkelerin saydığımız durumlar noktasında da dünya standartları üstünde oldukları bilinen bir gerçektir. Bu nedenle bu veriler üzerinden çokkültürcülük politikalarıyla sosyal sermaye arasında olumlu bir ilişkinin olduğunu ileri sürmek zor olmasa gerektir. Çünkü sosyal sermayesi yüksek olan ülkeler demokrat, çoğulcu, refah seviyesi yüksek, kültürel çeşitliliğe iyi gözle bakan yani çokkültürcü ülkelerdir. Bunun yanı sıra kendine has bir şekilde bu özellikleri barındıran toplumlar, çokkültürcülük ve sosyal sermayeden müteşekkil makro düzeyde bir bütünleşme örnekliği göstermektedir denebilir.

\section{Sonuç}

İçinde yaşadığımız dünyada neredeyse toplumların tamamı homojen olma durumunu kaybetmiş durumdadır. Yani çoğu devlet pek çok çeşitliliği bünyesinde barındırmaktadır. Etnik, kültürel, dini vs. çeşitlilikler, potansiyel olarak ayrılıkçılığa ve çatışmalara kaynaklık edebilmektedir. Toplumsal bütünleşme, modern dönem toplumların içinde bulunduğu çeşitlilikleri barışçı yollarla çözme noktasındaki en önemli hedeflerdendir. Bu hedefe hizmet eden iki önemli ve ilişkili yaklaşımın sosyal sermaye ve çokkültürcülük olduğu söylenebilir. Çokkültürlülük (kültürel çeşitlilik) kendinden yararlanılabildiği yani çokkültürcülük politikaları izlenebilindiği sürece sosyal sermayenin gelişmesine faydalar sağlayabileceği gibi, tersi bir durum da sosyal sermayeye zarar verebilecek türden problemlere kaynaklık edebilmektedir. Bu ayrılıkçı ve çatışmacı durumların aksine sürdürülebilir bir kalkınma sosyal sermayenin, istikrarlı bir barış ise çokkültürcülüğün hedefi olarak kabul edilebilir. Sürdürülebilir bir kalkınma için istikrarlı bir barış, istikrarlı bir barış içinse sürdürülebilir bir kalkınma kaçınılmazdır. Bu açıdan sosyal sermaye ve çokkültürcülüğün korelasyon içerisinde olduğu ve neticeleri gereği toplumsal bütünleşmeye imkân sağladıkları söylenebilir. Her iki yaklaşımın bu iddialarına dair ciddi eleştiriler olsa da yapılan çalışmalar göstermektedir ki her ikisinin de iddiaları pek çok toplumda tutarlılık göstermektedir. Yukarıdaki tablolar da göstermiştir ki pek çok sosyal güven indeksinin yüksek olduğu ülkede çokkültürcülük de yüksek çıkmıştır. Eş deyişle sosyal sermaye göstergeleriyle çokkültürcülük göstergeleri birbirlerini destekler niteliktedir. Bu bağlamda çokkültürcülüğün 
bir politika olarak kendine yer bulabildiği ülke ve toplumlar sosyal sermaye açısından güçlü, sosyal sermayesi yüksek olan ülkeler de çokkültürcülük politikalarının izlendiği ülkelerdir denebilir. Bunun yanı sıra bu ülkelerde kurumlara güven, fikri mülkiyet, sivil hak ve özgürlüklerin de dünya ülkeleri standartlarının üzerinde olduğu ve bunların özellikle sosyal sermayenin yüksek olmasına ciddi katkılar sunduğu malumdur. Farklılıklarla birlikte yaşamayı becermenin belli başlı maliyetleri vardır ve bunu başarabilmiş toplumlar, bu maliyetlerin karşılığını istikrarlı bir barış ve sürdürülebilir bir kalkınma şeklinde almaktadır. Neticede ortaya çıkan sürdürülebilir bir kalkınma ve istikrarlı barışın karşılığı olarak okunabilecek çokkültürcülük ve sosyal sermaye, toplumsal bütünleşmenin en önemli parametreleri olarak sayılabilir.

\section{Kaynakça}

Ağcasulu, Hülya (2017), "Sosyal Sermaye Kavramı ve Temel Bakış Açılarının Karşılaştırılması”. Süleyman Demirel Üniversitesi Vizyoner Dergisi, s. 8 (7), ss. 114-129.

Anık, Mehmet (2012), Kimlik ve Çokkültürcülük Sosyolojisi. İstanbul: Açılım Kitap Yayınları.

Aydemir, Mehmet Ali ve Özşahin. M. C. (2011), “Türk Demokrasisinde Kayıp Halkayı Keşfetmek: Türkiye Örneği Üzerinden Sosyal Sermaye-Demokrasi Bağlantısını Yeniden Düşünmek". Akademik Incelemeler Dergisi, s. 6 (1), ss. 41-87.

Banting, K. and Kymlicka Will (eds) (2006), Multiculturalism and the Welfare State: Recognition and Redistribution in Contemporary Democracies, Oxford: Oxford University Press.

Berger, Peter L. (2006), Sekülerizmin Gerilemesi, Medeniyetler Çatışması içinde, Der. Murat Yılmaz, Ankara: Vadi Yayınları.

Beşer, Ali Hadar ve Hira, İsmail (2017), “Sosyal Sermayeye Eleştirel Bakmak”. Afyon Kocatepe Üniversitesi Sosyal Bilimler Enstitüsü Dergisi, s. 1, ss. 23-37.

Büyükilikmen, A. Y. (2015), "Sosyal Sermaye ve Ölçülmesi”. Selçuk Üniversitesi Sosyal ve Teknik Araştırmalar Dergisi, s. 10, ss. 45-52.

Coleman, James S. (1990), Foundation of Social Theory. Cambridge: MA: Harvard University Press.

Fine, Ben (2010), "Sosyal Sermaye”. Sosyal Sermaye Kuram Uygulama Eleştiri içinde, Der: M. M. Şahin ve A. Z. Ünal, (çev: Ö. F. Peksöz ve M. M. Şahin), İstanbul: Değişim Yayınları.

Fukuyama, Francis (2002), "Social Capital and Development: The Coming Agenda". SAIS Review, 22(1), ss. 3-37.

Fukuyama, Francis (2009), Büyük Çözülme. (Çev. Hasan Kaya), İstanbul: Prodil Yayınları.

Fukuyama, Francis (2010), "Sosyal Sermaye ve Sivil Toplum". Sosyal Sermaye Kuram Uygulama Eleştiri içinde Der: M. M. Şahin ve A. Z. Ünal, (Çev: S. Tekel), İstanbul: Değiş̧im Yayınları.

Grooteart, Christiaan (2010), “Sosyal Sermaye: Kayıp Halka”. Sosyal Sermaye Kuram Uygulama Eleştiri içinde, Der., Mehmet Murat Şahin, Ahmet Zeki Ünal, (çev. N. Öztürk ve H. M. Arslan), İstanbul: Değişim Yayınları.

Giddens, Anthony (1994), Modernliğin Sonuçları. (çev. Ersin Kuşdil), İstanbul: Ayrıntı Yayınları. 
Güleç, Firdevs (2019), "Sınıf Öğretmenlerinin Kültürel Sermaye Yeterlilikleri ile Çokkültürlü Eğitime Yönelik Tutumlarının İncelenmesi: Siirt İli Örneklemi”. Yayınlanmamış Yüksek Lisans Tezi, Afyon.

Habermas, Jürgen (2010), “Demokratik Anayasal Devlette Tanınma Savaşımı”. Haz. Amy Gutmann, Çokkültürcülük: Tanınma Politikası, (çev. Mehmet H. Doğan), İstanbul: Yapı Kredi Yayınları.

Habermas, Jürgen (2010), “Öteki” Olmak, “Öteki”yle Yaşamak. (çev. IIlknur Aka), İstanbul: Yapı Kredi Yayınları.

Harriss, Jhon and Renzi, P. D. (2010), “Sosyal Sermaye Kavramı: ‘Kayıp Halka’mı Yoksa Analitik Olarak mı Kayıp? Bibliyografik Bir Giriş Denemesi”. Sosyal Sermaye Kuram Uygulama Eleştiri içinde, Der: M. M. Şahin ve A. Z. Ünal, (çev: M. Çelik ve M. M. Şahin), İstanbul: Değişim Yayınları.

Karagül, Mehmet and Masca Mahmut (2005), "Sosyal Sermaye Üzerine Bir İnceleme”. Ekonomik ve Sosyal Araştırmalar Dergisi, s.1, ss. 37-52.

Kesler, Christel and Irene Bloemraad (2010), Does Immigration Erode Social Capital? The Conditional Effects of Immigration-Generated Diversity on Trust, Membership, and Participation across 19 Countries, 1981-2000. Canadian Journal of Political Science, 43 (2): 319-347.

Kılınç, Zeynel Abidin (2010), “Yurttaşlık Ahlakı Olarak Sosyal Sermaye”. Bilgi, s. 21, ss. 1-37.

Konuralp, E. (2018), "Kimliğin Etni ve Ulus Arasında Salınımı: Çokkültürcülük mü Yeniden Kabilecilik mi?”. Eskişehir Osmangazi Üniversitesi IïBF Dergisi, 13(2), 133-146.

Kymlicka, Will (1998), Çokkültürlü Yurttaşlık-Azınlık Hakların Liberal Teorisi. (çev. Abdullah Yılmaz), İstanbul: Ayrıntı Yayınları.

Kymlicka, Will (2006), “Yükümsüz Özne”. (çev. Özlem Üskül Engin ve Murat Develioğlu), Cemaatçiler ve Liberaller içinde, Ankara: Dost Yayınları.

Kymlicka, Will (2012), Multiculturalism: Success, Failure, and the Future, Migration Policy Institute, Washington, DC.

Modood, Tariq (2014), Çokkültürcülük Bir Yurttaşlık Tasarımı. (çev., İsmail Yılmaz), İstanbul: Phoenix Yayınları.

Olate, Rene D. (2003), "Local Institutions, Social Capital and Capabilities: Challenges for Development and Social Intervention in Latin America". Center For New Institutional Social Sciences Seminars, Washington University, October 29.

Okumuş, Ejder (2017), Güven Toplumu. Ankara, Maarif Yayınları.

Özcan, Burcu and Zeren Fatma (2013), "Sosyal Güven ve Ekonomik Kalkınma: Avrupa Ülkeleri Üzerine Mekânsal Ekonometri Analizi”. Eskişehir Osmangazi Üniversitesi IïBF Dergisi, 8(1), ss. 7-36.

Parekh, Phuki (2002), Çokkültürlülüğü Yeniden Düşünmek. (çev. Bilge Tanrıseven), Anakara, Phoenix Yayınları.

Putnam, Robert (1993), Making Democracy Work: Civic Tradations in Modern Italy. New Jersey: Princeton Universty Press.

Putnam, Robert (2010), “Tek Başına Bowling: Amerika’nın Azalan Sosyal Sermayesi”. Sosyal Sermaye Kuram Uygulama Eleştiri içinde, Der: M. M. Şahin ve A. Z. Ünal, (çev: T. Ulutaş ve M. M. Şahin), İstanbul: Değişim Yayınları.

Roccefeller, Steven C. (2010), “Yorum”. Çokkültürcülük Tanınma Politikası, İstanbul: Yapı Kredi Yayınları. 
90 | Yılmaz Ceylan

Sertkaya, Burak ve Özcan, Günay (2017), "Sosyal Sermayenin Ekonomik Gelişme Açısından Önemi: Gelişmiş ve Gelişmekte Olan Ülkeler Üzerine Bir Değerlendirme”. Bulletin of Economic Theory and Analysis, 2(1), ss. 1-12.

Smart, Alan (2008), “Social Capital”. Anthropologica, 50 (2), pp. 409-416.

Şan, Mustafa Kemal (2006), “Küreselleşme Çağında Farklılık ve Çokkültürlülük Siyaseti”. Avrupa Günlüğü EUROAGENDA- 8, ss. 299-335.

Şan, Mustafa Kemal ve Akyiğit, Handan (2015), "Sosyal Sermaye Tartışmaları ve Türkiye'de Sosyal Sermayenin Ölçülmesi Sorunu”. Selçuk Üniversitesi Sosyal Bilimler Enstitüsü Dergisi, 34, ss. 123-134.

Taylor, Charles (2010), “Tanınma Politikası”. Çokkültürcülük, Edt. Amy Gutmann, İstanbul: Yapı Kredi Yayınları., ss. 25-73.

Taylor, Charles (2011), Modernliğin Sıkıntıları. (çev. Uğur Canbilen), Ayrıntı Yayınları, İstanbul.

Tecim, Erhan (2011), Sosyal Güven Sosyal Sermaye ve Dindarlık Çalışması. Konya: Çizgi Kitabevi.

Tekinalp, Şermin (2005), “Küreselleşen Dünyanın Bunalımı: Çokkültürlülük”. Journal of İstanbul Kültür University, 3 (1), ss. 75-87.

Tok, Nafiz (2003), Kültür, Kimlik ve Siyaset-Kültüre İlişkin Meseleler Için Kimlik Temelli Bir Yaklaşım, İstanbul: Ayrıntı Yayınları.

Uğuz, Hülya Örseli, Erhan Sipahi Esra Banu (2011), “Sosyal Sermayenin Ölçümü: Türkiye Deneyimi”. Akademik Incelemeler Dergisi, 6, (1), ss. 8-40.

Woolcock, Michael and Narayan Deepa (2000), "Social Capital: Implications for Development Theory, Research, and Policy". World Bank Research Observer, Vol. 15 (2), pp. 225-249.

Woolcock, Michael (2003), "Social Capital”, Encyclopedia of Community. Edt. K. Christensen and D. Levinson, 1258-1262, Sage Publications, London.

Yarcı, Selman (2011), “Pierre Bourdieu'da Sosyal Sermaye Kavramı”. Akademik Incelemeler Dergisi, 6 (1), ss. 125-135.

Zizek, Slovaj (2011), Kırılgan Temas. (çev. Tuncay Birkan), İstanbul: Metis Yayınları.

Walzer, Michael (2010), "Yorum”. Çokkültürcülük Tanınma Politikası, Haz. Amy Gutmann, (çev. Cem Akaş), ìstanbul: Yapı Kredi Yayınları.

World Values Survey Association, World Values Survey, http://www.worldvaluessurvey.org/ wvs.jsp. Erişim tarihi: 05.12.2020. 